\title{
Society Response to Mobile Services on Mobile on The Road Investment Services and Integrated One-Stop Licensing Services in Tebing Tinggi City
}

\author{
Andy Akbar Perdana ${ }^{1}$, Badaruddin Agus $^{2}$, Suriadi ${ }^{2}$ \\ ${ }^{1}$ Master student State University of North Sumatera (USU), Medan, Indonesia \\ ${ }^{2}$ Lecturer in State University of North Sumatera (USU), Medan, Indonesia \\ Email : andyakbarperdana@gmail.com
}

\begin{abstract}
:
The aim of this study is to find out the society response Mobile Services on Mobile on The Road Investment Services and Integrated One-Stop Licensing Services in Tebing Tinggi City. This research was conducted at the Investment Office and the One-Door Licensing Service of Tebing Tinggi City. The result of this study The response given by every community that has taken care of business permits is also quite good, they feel satisfied that they have been well served by Mobile On The Road officers who are well served to arrive at the stage of delivering ready-made letters to them. Keywords :

government; society response; investment services; licensing service
\end{abstract}

\section{Introduction}

The paradigm of organizing government has now shifted from government to governance. Good government (good governance) is necessary for the new paradigm to work well to achieve its goals, namely well-being and justice. The urgency of the "Good Governance" paradigm in responding to the above is to keep the "serving" function of public service through accountability, although under the conditions some such sectors of service have been given to the private/business sector. People are specified to be a society entitled to receive public services need to be granted access to monitor and evaluate the performance of public services.

Soeprapto (2005) argues that the government is not built to serve its own needs, but aims to serve the needs and interests of the community and create conditions that allow each member of the community to develop their abilities and creativity to achieve common goals. Public service by the public bureaucracy is one manifestation of the functions of the state apparatus as public servants as well as state servants.

The government's efforts to improve the quality of public service as a policy determinant by utilizing the momentum of implementing local autonomy have been made. At least some service innovations of one are the Around Services (Mobile On The Road) policy on the Capital Planting Service and the One-door Licensing Service in the Tebing Tinggi City. The goal of making changes in a better direction in different sectors, one of which was to change the function of local government that had originally been as a promoter of development turned into a community servant.

A wide variety of wild levies became complaints of investors in the area when it took care of the licensing of its investments. Coupled with the uncertainty of the completion time of licensing services became a classic problem in licensing services in the era of regional autonomy. Pull withdrawing the authority of licensing fields is still happening. Some sectors are still under the control of technical services or directly under the control of regional heads. In addition the obscurity of the form of the institution where there is still a separation between licensing services 
with the field of capital planting. The separation is certainly incriminating for investors having to deal with two different agencies. The central government has therefore encouraged and facilitated improvements to this licensing service by issuing a One-door Integrated Service (PTSP) policy through No. 24 Traders of 2006.

Tebing Tinggi City is one of the areas that applies the policy of the Ministry of Home Affairs. This can be seen from the results of the related Regional House of Representatives (DPRD) decisions stipulated in the Government Regulation No.18 Year 2016, regarding typology and national nomenclature, Integrated Licensing Service Office (KP2T) being a Type B Service. namely the Mo'dal Planting Service and the One-Stop Integrated Service, Tebing Tinggi City made changes by combining KP2T with the Investment Board (www.kp2t.tebingtinggi.com).

The One Stop Integrated Service policy aims to create an integrated service system where the management process of several types of services is carried out in an integrated manner in one place. Even in Government Regulation No. 96 of 2012 specifically Article 15 paragraph (2) it is affirmed that a one-door integrated service system must be implemented for the types of licensing services and non-licensing in the field of investment.

\subsection{Theories of Public Policy}

\section{Review of Literature}

Basically, there are many limitations or definitions of what is meant by public policy in the literature. Each of these definitions places different emphasis. This difference arises because each expert has a different background. While on the other hand, the approaches and models used by experts will ultimately determine how public policies are to be defined (Winarno, 2007: 16).

Public policy is a policy-making process by the government or holders of power that has an impact on the wider community. The new policy process starts when policy actors begin to realize that there are problem situations, namely situations that are perceived as having difficulties or disappointments in formulating needs, values and opportunities. Public policy is also a process of governance and government administration that results in government decisions, where relevant agencies have authority or power in directing society and responsibility to serve the public interest (Naihasy, 2006: 18).

Public policy provides a direction for action for future behavior while at the same time being a unified direction for a number of programs and projects that require large and small decisions. The direction of this action is generated through the selection process by policy makers from a number of alternative choices available so that this action is deliberate action. The choice does not mean to solve all problems, but provides a solution to a limited situation.

\subsection{Public Services}

Definition of Public Services According to the Rasyid public service is the provision of services (serving) the needs of people or communities who have an interest in the organization in accordance with the basic rules and procedures that have been set. Government in essence is service to the community. He is not held to serve himself, but to serve the community and create conditions that allow each member of the community to develop their abilities and creativity to achieve common goals (Hardiansyah 2011: 14).

Soeprapto (2005) argues that the government is not built to serve its own needs, but aims to serve the needs and interests of the community and create conditions that allow each member of the community to develop their abilities and creativity to achieve common goals. Public service 
by the public bureaucracy is one manifestation of the functions of the state apparatus as public servants as well as state servants.

In the Decree of the Minister of Administrative Reform No.63 of 2003 states that the definition of public services is all service activities carried out by providers of public services as an effort to fulfill the needs of recipients of services and the implementation of the provisions of 18 laws and regulations. Then according to MENPAN No.63 of 2004 states that the nature of public service is the provision of excellent service to the community which is the realization of the obligations of government officials as public servants. (Ratminto \& Winarsih 2010: 18), According to Law No. 25 of 2009 concerning Public Services article 1 paragraph (1), public service is an activity or series of activities in order to fulfill service needs in accordance with legislation for every citizen and occupation of goods, services or administrative services provided by public service providers.

According to Moenir in his book Public Service Management in Indonesia (2006: 26), the notion of public service is an activity carried out by a person or group of people on the basis of material factors through certain systems, procedures and methods in order to fulfill the interests of others according to their rights. According to Hardiansyah (2011: 11) public service is the provision of services by the government or the private sector to the community, with or without payment to meet the needs and or interests of the community.

Based on the description above, the public service in this study can be interpreted as providing services for the needs of people or communities who have an interest in the organization in accordance with the basic rules and procedures set by the government. Then, public service providers, namely each state-run institution, corporation, independent institution formed based on the law for public service activities, and other legal entities formed solely for public service activities.

The existence of bureaucracy as an instrument of government is expected to provide quality public services. Apparatus as public servants must be able and willing to respond to the development of community needs. In Law No. 23 of 2014 shows the extent of the role of the Regional Government in the field of public services, as a form of realization of the application of the principle of broad regional autonomy.

Based on Law No. 23 of 2014, the attention of the public bureaucracy during the regional autonomy is real, extensive and responsible for satisfying services for the community. One public service that focuses on research is concerning bureaucratic innovation in licensing services in Tebing Tinggi City, namely Mobile On The Road in the Investment Service and One-Stop Integrated Licensing Service (DPMPPTSP). This service is one of the pillars and supporters in the implementation of Regional Autonomy, in this case there is regional financial income (PAD) from the licensing sector.

The public policy paradigm in the era of customer satisfaction-oriented regional autonomy provides direction for changes in the mindset of local government apparatus, in addressing changes and/or shifts in the paradigm of organizing service-oriented local governments. The policy of organizing local government that was originally based on the goverment rule paradigm that is, which puts forward procedures, shifts into a good governance paradigm that puts forward togetherness, transparency, accountability, justice, equality and legal certainty. 


\section{Method}

This research was conducted at the Investment Office and the One-Door Licensing Service of Tebing Tinggi City. This is because at this office made a new policy in providing public services for the people of Tebing Tinggi City. So that researchers are interested in knowing more about this policy.

\section{Discussion}

The performance measurement of Mobile On The Road in facilitating small entrepreneurs to have business permits can also be seen from the quality of services provided by officers or employees of the Mobile On The Road in Tebing Tinggi City to the people who own businesses. Quality of service itself describes the quality of services provided and the suitability of service users for services provided, therefore measuring the quality of mobile services is determined by the assessment of service users. Service users can assess the services provided, whether they are as expected or not.

Service users, in this case the society who have businesses or business license applicants, will be satisfied if the services provided are in accordance with what is expected, and vice versa, if the services provided are not as expected, service users are not satisfied. To assess the quality of mobile services around Mobile On The Road, indicators for research are needed, namely the reliability of employees in providing services as well as guarantees given to entrepreneurs who manage business permits, as well as empathy, namely hospitality of officers in providing services.

\subsection{Reliability}

Reliability is the ability to provide services immediately and satisfactorily. In this case, it can be seen from the readiness or speed of employees in serving the community who will drain the business permit and mastery of the material in providing information to the community. Users of Mobile On The Road service hope that every time they come to the lurah office or when they go directly to their place of business to apply for permission and find out information about what they want to know regarding permit management, they get what they are looking for and get fast and appropriate service, especially in the issuance of business licenses.

Ms. Hairani Siregar 46 Years:

"if this Mobile On The Road Around Service its employees always give full info on the terms of making the filing of his permit bang, if we go to the office directly inaugurated, long, keep the employees friendly. Anyway the service provided by this traveling service the forest of its employees is not disappointing".

The same thing was said by Mr. Suwarno 48 years:

"Employees here are also very careful about the completeness of the terms of the permit application, one condition is that the customer is told to immediately complete so that the permit can come out on time and they do not force us, so they are like a service that keeps us informed they check our files, then they will be handed over to us if we want to take care of them or go directly to the service. So it's really good performance"

The same thing was also expressed by Mr. Mulkan 42 Years:

"Here the staff is friendly, Bang, it works too fast, not long-winded. When I took care of my permission because I happened to have completed my file tomorrow, my business 
permit was delivered. But if our files are not complete, we are usually told to complete first and then they come again. Usually for a maximum of three days it's finished bang. So far, if I judge, the presence of mobile services is very helpful. "

The statement expressed by Ms. Ratna Kesuma Panjaitan, SE as Head of Complaints, Policy and Reporting:

"Employees or officers who run the Mobile On The Road mobile service program have received special training on personality, namely how to greet customers, serve quickly, precisely and of course friendly, after that they are selected to become officers for this mobile service. Because our main goal in this program is to improve the mindset of the people who have businesses to manage their business permits so that the business is legal according to the provisions. Then we have to change their statutes about the old, complicated management, fussy officers and so on "

Based on the statements from the informants above, it shows that reliability, in this case the speed of employees in serving customers and the accuracy of the information provided by officers to customers, is in accordance with the expectations of its customers or can be said to be very good because so far customers feel satisfied with the work of Mobile On The Road Mobile Services officers in Tebing Tinggi City.

\section{2. Assurance of Reassurance}

Positive views will come to public service organizations if someone or customer feels a guarantee or certainty in the service provided in the service process. Assurance / assurance is the ability of the organization to provide trust to customers, in this study certainty is measured by clarity and certainty regarding service procedures, details of service costs, timetable for completion of services, rights and obligations of both the provider and recipient of the service. As expressed by Mr. Suriadi, S.Pd, M.Pd as the acting officer of the Tebing Tinggi City Investment and Integrated Licensing Service Office:

"This Mobile On The Road program is one of the public service facilities in the licensing sector, so it has a working time per month visiting one sub-district, where each week it will take turns to go to the urban villages even to the community unit location directly, for service time always disciplined and on time in accordance with predetermined procedures, so indeed the services carried out are full of assurance, so that the community can change the set that the permit is fast, sure and not expensive "

As expressed by Mr. Sutan 53 years as follow :

"Information about the terms of the business permit to the extent of the cost and the length of time the permit was granted, it has been detailed and very clear, so I can know about the cost to make the permit what is the total and so far it is very suitable. There are no changes or additional costs made by the officer. Because the provision was shown to us in the form of a letter that had been signed by the head of the department and the mayor. So I don't think it's possible that the information was falsified by the officers. "

The same thing was expressed by Mr. Suwarno 48 years:

"This permit was made 3 days ago, faster than the time specified. Because the provisions are scheduled to be completed within 7 days. I knew that my permit had become faster, so from the official's side I was sent directly to my place of business. So we don't bother to take it to the dinas office. In my opinion, the services provided by the officers are quite good. We also have security if for example they want to cheat we can report directly to the department. We were told the official identity" 
Based on the statements above, it can be concluded that assurance, starting from certainty about service procedures, details of service costs, schedule for completion of services, rights and obligations of both the giver and recipient of the service, can be said to be guaranteed. The problem of delay that arises from the officers themselves, there have been consequences from the service later. This is done to continue to gain the trust of the customers so that customers, especially the new people, build businesses to manage their business permits.

\subsection{Empathy}

The concept of empathy is directed to give full care to customers, which includes ease of relationship, good communication, personal attention and understanding the needs of customers. In this study the indicators used to assess empathy are the ability of Mobile On The Road officers to be easily contacted and communicate and hospitality to customers. Sometimes the applicant's permission to be treated more by officers and special services such as providing information directly via telephone. Following are the statements of the Head of the Integrated One-Stop Investment and Licensing Service Office of Tebing Tinggi City, Mr. Suriadi, S.Pd, M.Pd:

"In order to establish communication with the community / consumers, we do it in addition to friendly service and socialization and are ready to provide the necessary information. For example, if the next day there will be a field check, the officers call to let them know. Or if there is an incoming call from the people who send the permission, we will immediately lift it and give the information needed. In addition, we also open opportunities for customers to give input on what services they want. "

The same thing was also expressed by Ms. Ratna Kesuma Panjaitan, SE as Head of the Complaints, Policy and Reporting Division:

"To establish communication with the permit applicant, we do socialization and are ready to provide the necessary information face to face. Furthermore, we press the officials to explain the interests of the people who have the business to manage their needs first, such as files that must be completed by them. In other words the officers must be prepared if contacted repeatedly by the party who wants to take care of the permit."

Regarding the convenience of being contacted and communicating, some people who manage business licenses give their opinions. The following are the results of interviewing researchers with them:

Ms. Heriani Siregar comments:

"Yes sir, they are easy to contact, before I went before this traveling officer once permitted a business permit, but waiting for the officer to check the field did not come, so I lazily returned to the service office to take care of him. It's only now that I take care of it again because it's already been around like this. It's easier to contact, we are also easy to ask about the terms and fees"

In addition to the ease of making communication links for customers with Mobile On The Road officers they also get service quickly and with great hospitality. As expressed by Mr. Suwarno as follows:

"The officers of the mobile on the road are attentive and compact, they have fulfilled my expectations as users, unlike other civil servants we often see chatting and reading newspapers, and are usually indifferent to customers, my mobile service feels more time efficient and more friendly" 
Based on the above statements, the customers feel that they have been taken care of by the Investment and Integrated One-Stop Licensing Service and are satisfied with what has been provided from this mobile service policy. When confirmed about a number of statements from the people who took care of business licenses that considered this mobile service had given good empathy to customers. Mr. Suriadi, S.Pd, M.Pd as the acting head of the Tebing Tinggi City Investment and Integrated One-Stop Licensing Service said:

"The service here is trying to find out what the people want as applicants for permission. Before the existence of this mobile service, there was a growing issue regarding the licensing of this business, the procedure was difficult, the deadline for settlement was uncertain, there were many charges, the officers were not friendly. From this issue we were able to find out what the applicant's wishes meant they wanted certainty of time, friendliness, easy procedures, transparent costs. We know that desire and then we try to fulfill that desire by making this mobile service policy. "

In addition to the above opinion, Suriadi, S.Pd, M.Pd, as the acting head of the Tebing Tinggi City Investment and Integrated One-Stop Licensing Service also added:

"In addition, the officers were also given direct training in service ethics, namely personality training, before being hired in Mobile On The Road, so that in dealing with permit applicants who have different characteristics, officers can be responsive about the steps that must be taken. For example, if there is an impotent permit, it means that we must pay more attention and the employee must be more patient. Besides that, every time there are applicants who need help, they are immediately assisted so that they always feel cared for.

The implementation of the service process does not always go as expected. There are factors that influence the service process that exists in a service organization. These factors exist that are inhibiting and supporting the performance of an organization. In this study, aside from discussing the implementation of mobile services, the response from the community, researchers also examined the obstacles that hampered the mobile service process that had been going on for three years in Tebing Tinggi City in issuing business licenses. The obstacles in this mobile service include:

1. The total and condition of official cars that are inadequate for the implementation of this tour, so far each month it still takes turns using the official car.

2. The lack of validity of the data provided by the applicant's permission, some of the obstacles that occur in mobile services actually come from the people who make the permit application themselves. Permits that are late issued are generally due to files provided by the customer in the data fulfilling the licensing requirements, some of which are invalid or even fake. The lack of validity of data provided by the applicant is mostly because the identity data has expired.

\section{Conclusion}

The response given by every community that has taken care of business permits is also quite good, they feel satisfied that they have been well served by Mobile On The Road officers who are well served to arrive at the stage of delivering ready-made letters to them.

Obstacles faced by the Tebing Tinggi City Investment and Integrated One-Stop Licensing Service in implementing mobile service policies as a manifestation of community service innovation engaged in licensing, specifically the issuance of trade business licenses include the 
following: Amount and condition of official cars inadequate and less valid data provided by the applicant's permission.

\section{References}

Arikunto, Suharsimi. 2010. Prosedur Penelitian Suatu Pendekatan Praktek. Jakarta : Rineka Cipta.

Darwin. Muhadjir. 2005, Negara dan Perempuan: Reorientasi Kebijakan Publik. Graha Guru dan Media Wacana,

Ginting, Paham. 2006. Filsafat Ilmu dan Metode Penelitian. Medan : usupress.

Hasan, M.Iqbal. 2002. Pokok - pokok Metodologi Penelitian 7 Aplikasinya. Ghalia Indonesia.

Hasibuan, Malayu S.P. 2007. Manajemen Dasar : Pengertian, dan masalah, edisi revisi. Jakarta : Bumi Aksara.

Huda, Ni'matul. 2005. Otonomi Daerah, filosofi, sejarah perkembangan dan problematika. Yogyakarta : Pustaka Pelajar,

Ibrahim, Amin. 2004. Pokok - Pokok Analisis Kebijakan Publik. Mandar Maju.

Idrus. Muhammad. 2009. Metode Penelitian Ilmu Sosial Pendekatan Kualitatif dan Kuantitatis. Jakarta. Erlangga.

Indiahono, Dwiyanto. 2009. Kebijakan Publik, Berbasis Dynamic Policy Analysis. Yogyakarta : Gava Media

Luankali, Bernadus, 2007, Analisis Kebijakan Publik Dalam Proses Pengambilan Keputusan,Amelia Press, Jakarta.

Moleong, Lexy J. 2011. Metodologi Penelitian Kualitatif. Bandung: Remaja Rosdakarya.

Moenir, HAS. 2001. Manajemen Pelayanan Umum di Indonesia, Jakarta : Bina.

Nawawi, Hadari. 1998. Metodologo Bidang Sosial. Yogyakarta : Gajah Mada.

Purwanto, Erwan Agus \& Sulistyatuti, Diah Ratih. 2012. Implementasi KebijakanPublik, Konsep dan Aplikasinya di Indonesia. Yogyakarta : Gava Media

Ratminto, and Wianarsih, Atik, 2013, Manajemen Pelayanan. Yogyakarta: Pustaka Pelajar, Rohman, Ahmad Ainur dkk. 2008. Reformasi Pelayanan Publik. Program Sekolah Demokrasi,

Sitorus, Monang, 2013. Teori Kebijakan Publik: Formulasi Implementasi Evaluasi. Unpad Press.

Subarsono. Ag. 2003. Analisis Kebijakan Publik. Modul Kuliah. MAP-UGM, Yogyakarta,

Sugiyono. (2012). Metode Penelitian Kuantitatif Kualitatif Dan R\&D. Bandung: Alfabeta

Suharno. 2008. Prinsip - Prinsip Kebijakan publik. Yogyakarta : UNY Press

Sunggono, Bambang. 1994. Hukum dan Kebijaksanaan Publik. Jakarta: Sinar Grafika.

Tangkilisan. Hessel. 2003. Implementasi Kebijakan Publik, Transformasi Pikiran George Edward. Yogyakarta : Lukman Offset.

-----2003. Kebijakan Publik Yang Membumi. Yogyakarta. Lukman Offset

Wahab, Abdul. 2008. Pengantar Analisis Kebijakan Publik. Malang: UMM

Wasistiono, Sadu dkk. 2002. Menata Ulang Kelembagaan Pemerintah Kecamatan. Bandung: Citra Pindo ------2009. Perkembangn Organisasi Kecamatan dari masa Ke masa. Bandung : Fokusmedia

Wayne, Parson. 2005. Public Policy : Pengantar Teori dan Praktik Analisis Kebijakan. Jakarta : Prenada Media.

Winarno, Budi. 2007. Kebijakan Publik, Teori dan Proses. Jakarta : Media Pressindo.

\section{Scientific Journal Source:}

Ananda, Yundhi. 2016. Strategi Inovasi Pelayanan Terpadu Penanaman Modal dalam Pelayanan Periæinan di Kota Pekanbaru Vol 8 No 1. Jurnal Ilmu Administrasi Negara. Universitas Riau

Dewi, Puspita. (2012). Inovasi Pelayanan Perizinan dalam Peningkatan Pendapatan Asli Daerah (PAD) Pada Kantor Pelayanan Perizinan Terpadu Satu Pintu Kota Makasar Vol 6 No 2. Jurnal Ilmu Pemerintahan. Universitas Hasanudin.

Evi Ulmilasari. 2013. Analisis Pelayanan Perizinan di Badan Perizina Terpadu dan Penanaman Modal Kota Makassar Vol 6 No 1. Jurnal Ilmu Pemerintahan. Universitas Hasanuddin 
Leny Ismayanti. 2015. Efektifitas Penyelenggaraan Pelayanan Perizinan Terpadu Satu Pintu di Kabupaten Malang Vol 4 No 2. Jurnal Ilmu Sosial dan Ilmu Politik. Universitas Brawijaya Malang

Suciana, Yunananda.2016. Dampak Kebijakan Pelayanan Perizinan Terpadu Satu Pintu Terbadap Daya Tarik Investor di Kota Bandung. Jurnal Ilmu Ekonomi Pembangunan. Universitas Pasundan

Yuli, Tirtariandi. 2014. Implementasi Kebijakan Pelayanan Perizinan Terpadu Satu Pintu Kota Bangka. Jurnal Ilmu Administrasi Negara. Univeristas Terbuka

Wulandaril, F.R. 2013. Model Implementasi Kebijakan Sistem Pelayanan Perizinan Satu Pintu Kabupaten Jembaran. Jurnal Ilmu Adminitrasi Negara. Universitas Terbuka

\section{Peraturan Perundang - Undangan:}

Undang - Undang Dasar 1945.

Undang-Undang Nomor 25 Tahun 2007

Undang-Undang Nomor 23 Tahun 2014 tentang Pemerintahan Daerah.

Peraturan Pemerintah Nomor 96 Tahun 2012

Peraturan Pemerintah Nomor 18 Tahun 2016

Peraturan Pemerintah Nomor 12 Tahun 2017

Peraturan Menteri Dalam Negeri Nomor 24 Tahun 2006

Peraturan Menteri Dalam Negeri Nomor 73 Tahun 2009 Tentang Tatacara Pelaksanaan Evaluasi Kinerja Penyelenggaraan Pemerintahan Daerah.

Peraturan Daerah Kota Tebing Tinggi Nomor 15 Tahun 2006

Peraturan Daerah Kota Tebing Tinggi Nomor 03 Tahun 2016

Surat Edaran Walikota Tebing Tinggi Nomor : 503/2417/KP2T/2015 